\title{
TTR
}

Traduction, terminologie, re?daction

\section{Audiovisual Communication and Language Transfer: the Strasbourg Conference, June 1995.}

\section{Luise von Flotow}

Volume 8, numéro 2, 2e semestre 1995

Technolectes et dictionnaires

URI : https://id.erudit.org/iderudit/037230ar

DOI : https://doi.org/10.7202/037230ar

Aller au sommaire du numéro

\section{Éditeur(s)}

Association canadienne de traductologie

\section{ISSN}

0835-8443 (imprimé)

1708-2188 (numérique)

Découvrir la revue

\section{Citer ce compte rendu}

von Flotow, L. (1995). Compte rendu de [Audiovisual Communication and

Language Transfer: the Strasbourg Conference, June 1995.] TTR, 8(2), 286-289.

https://doi.org/10.7202/037230ar d'utilisation que vous pouvez consulter en ligne.

https://apropos.erudit.org/fr/usagers/politique-dutilisation/ 


\title{
Audiovisual Communication and Language Transfer: the Strasbourg Conference, June 1995.
}

\begin{abstract}
"Audiovisual communication" is an area that has been left largely unaddressed in the current discourses of translation studies. This may be understandable given the fact that translation studies is a relatively new field, still establishing itself in academia; it may perhaps be even more understandable when we consider that many translation scholars (particularly in North America) have come from traditional literary studies, not communications or media studies or translator training institutes. Their literary interests and their focus on printed media, may however soon extend to respond to the research and development needs in "audiovisual communication and language transfer." It is a growing field.
\end{abstract}

Audiovisual communication and language transfer was the topic of one of the most interesting conferences I have attended in a long time. Held in Strasbourg, under the auspices of a number of national and international bodies, among them UNESCO, FIT, the French Ministry of Culture and the European Institute for the Media, and organized by a committee around Professor Yves Gambier(Turku, Finland), the conference brought together numerous translators and interpreters, professionals from dubbing/subtitling agencies, as well as representatives of radio and television broadcasting companies, academics, bureaucrats from the European Union and speakers from a number of European and North American cultural agencies.

The objectives of the conference organizers as presented in the first circular were twofold. On the one hand, they wanted to "reveal the cultural and identity stakes of languages in the production of AV works" in a number of ways: by discussing the various types of language transfer, their role in and their impact on questions of cultural difference, by stressing the importance of languages in AV exchanges (film imports, sales of TV programs, distribution of videos) and by shedding light on the criteria used when decisions about language policies and AV transfer are made. On the other hand, the organizers 
wanted to arouse the awareness of diverse professional bodies involved in $\mathrm{AV}$ communication, who "are usually unaware of, or underestimate the impact of, the problems of language transfer." Here, the purpose was oriented in a practical/ technical direction, with stress on the importance of languages at all stages in the life of an AV product (production, distribution, exploitation, broadcasting), emphasis on the financial and technical aspects of the various forms of language transfer (subtitling, dubbing, voice-over, narration, simultaneous interpreting), their quality control and copyrighting, and discussions of the impact that future developments (cable, satellite and digital broadcasting) will have on quality, working conditions and production time. Finally, they hoped to sketch the outlines of a European training course in the field. All this in three days.

The conference in fact fulfilled many of these expectations, and it stimulated much thought and discussion. It certainly provided masses of practical information as well as ideas (even pleas from practitioners) for new research projects. Reflecting the planners intentions, the conference took two major directions: an informative direction that was concerned with the many different practical problems that arise in the translation of audio-visual materials of the most diverse kinds; and an other, political, direction. While discussions of the practical aspects dominated the three-days of proceedings, these were inextricable from the constant undercurrent of political concerns. One such political issue could perhaps be simplified and summed up as the perceived need in Europe to counteract the deluge of USA-American audiovisual materials that, particularly after the deregulation of many television channels, is threatening European cultural heritage and linguistic plurality. Of course, other political issues, such as the problem of "nationally loaded" language transfer, and the struggles of minority (or formerly suppressed) languages such as Basque and Catalan were addressed, but an overwhelming need to resist the influences of American media giants seemed to predominate.

Thus, representatives of European policy-makers responsible for developing and implementing ways to support European cultural pluralism were important speakers who were heard in the plenary sessions of the conference: Jan Roukens (DG XIII-EU, Luxembourg), Tanja Virtanen (UNESCO, Sector for Communication and Information), Jean Yvane (BABEL: Broadcasting across the barriers of European Language/Fonds européen pour le multilinguisme audiovisuel) and Gabriele Mazza (in charge of Cultural Policy at the Council of Europe) discussed the programs they represent and paid tribute to the important work done by translators, interpreters, dubbers and subtitlers in the domain of intercultural contact in Europe. Such speakers also dominated the final roundtable discussion on "The European Audivisual Media of the Future" at which a final resolution was unanimously adopted. 
The diverse papers presented by practitioners and academics constituted the other, stimulating aspect of the conference. In two different sessions, translators, subtitlers and dubbers, and media interpreters from Finland to Spain, from Rumania to Belorussia and Latvia described their work, their working conditions and the economic and political factors affecting the language transfer they are involved in. And although conditions vary and resources are unequal, the problems seem to be rather similar: time constraints, technical, linguistic and culture-specific aspects of subtitling and dubbing, the problem of identifying and satisfying the viewer, and difficult economic conditions were issues that were reiterated. Speakers from the former East Bloc countries, addressed a number of explicitly political issues that had been sensitive points prior to 1989 , and went on to describe the economic problems now taking their place.

A roundtable session on the training programs for AV translation that are presently available brought together academics and businesspeople: Peter Spoor (Netherlands) and Mary Carroll (Germany) described the very similar programs of their companies: a six-week training scheme followed by six months of work experience under the guidance of a mentor. Jean Jacques Alcandre (Strasbourg) and Heulwen James (Lampeter, Wales) presented information on subtitling courses offered at university level, and drew attention to the recently formed European Association for Studies in Screen Translation, a forum for further academic discussion in the realm of AV transfer. In this session, the importance of politically instituted language policies was clearly visible: the Lampeter course is closely linked to Welsh language TV programming, and the work done in Strasbourg is at least partly due to the presence of Arte, the bilingual/bicultural television channel brought into existence through French/German economic and political cooperation.

The academic presentations focussed largely on political and intercultural aspects of AV translation. Ursula Ganz-Blaetter (Switzerland) showed how great an impact a country's history can have on film translation: the Nazi villains in an American action serial become Palestinians in one German version. Martine Danan (USA) argued that marketing techniques may determine the choice of the mode of transfer used for AV translation: the current vogue of subtitling American blockbusters in France is increasing the prestige of these products among a certain educated and upwardly-mobile sector of the population, who might avoid the dubbed versions. Audience reception studies were also the focus in papers by Irena Kovacic (Slovenia), Henrik Gottlieb (Denmark) and others, where the stress was on concepts such as "individual viewer" and "active customer" and the effects of parameters such as age, gender and educational background in the reception of translated AV materials were emphasized. 
In the parallel workshop sessions, topics included reception studies, copyright issues, technological tools and interpretation for the media. This last section raised some of the issues that need to be considered when interpretation occurs in public rather than "off-stage" in a conference interpreter's booth. Logistical problems arise, for example, when famous actors demand that the dubbing actor whose voice replaces theirs be on hand for live interviews. Presence and poise may be an issue if interpreters are required to appear live beside the celebrity they are speaking for. Interpretation in "on the spot" news coverage of events poses severe logistical problems for smaller countries and their media - how many interpreters is one likely to find (immediately) who can work from Serbian into Finnish? from Irish into Portuguese?

The conference not only served as a stimulating venue for the large mix of people working in the field of $\mathrm{AV}$ communication and language transfer, it also demonstrated the extent to which traditional distinctions between concepts such as language and country, translation and interpretation, written/ oral/visual texts and their various modes of language transfer are becoming blurred. Moreover, it made clear to what extent audiovisual productions are a result of teamwork where the tasks are no longer discrete and numerous activities need to be described, understood, coordinated and arranged to respond to economic and political conditions. Further, in the face of rapid technological changes it stressed the need for redefinition of the field, and posed numerous new questions for which research is required. While a certain amount of discussion was controversial, the goal of maintaining a multilingual and pluricultural Europe is one major issue that its participants seemed to be united on. In North America, the developmentand encouragement of a multilingual and pluricultural environment might well be the major issue.

For those little acquainted with the field, the following bibliography may be a good starting point: Yves Gambier, ed. Language Transfer and Audiovisual Communication, University of Turku, Centre for Translation and Interpreting, 1994, ISBN 951-29-0149-8. 